Article

\title{
Development of Somatic Embryo Maturation and Growing Techniques of Norway Spruce Emblings towards Large-Scale Field Testing
}

\author{
Mikko Tikkinen * (D), Saila Varis and Tuija Aronen \\ Natural Resources Institute Finland, FI-58450 Punkaharju, Finland; saila.varis@luke.fi (S.V.); \\ tuija.aronen@luke.fi (T.A.) \\ * Correspondence: mikko.tikkinen@luke.fi; Tel.: +358-29-532-8475
}

Received: 23 March 2018; Accepted: 12 May 2018; Published: 4 June 2018

\begin{abstract}
The possibility to utilize non-additive genetic gain in planting stock has increased the interest towards vegetative propagation. In Finland, the increased planting of Norway spruce combined with fluctuant seed yields has resulted in shortages of improved regeneration material. Somatic embryogenesis is an attractive method to rapidly facilitate breeding results, not in the least, because juvenile propagation material can be cryostored for decades. Further development of technology for the somatic embryogenesis of Norway spruce is essential, as the high cost of somatic embryo plants (emblings) limits deployment. We examined the effects of maturation media varying in abscisic acid $(20,30$ or $60 \mu \mathrm{M})$ and polyethylene glycol 4000 (PEG) concentrations, as well as the effect of cryopreservation cycles on embryo production, and the effects of two growing techniques on embling survival and growth. Embryo production and nursery performance of 712 genotypes from 12 full-sib families were evaluated. Most embryos per gram of fresh embryogenic mass (296 \pm 31 ) were obtained by using $30 \mu \mathrm{M}$ abscisic acid without PEG in the maturation media. Transplanting the emblings into nursery after one-week in vitro germination resulted in $77 \%$ survival and the tallest emblings after the first growing season. Genotypes with good production properties were found in all families.
\end{abstract}

Keywords: Norway spruce; Picea abies L. Karst.; somatic embryogenesis; forest biotechnology; forest regeneration material; cryopreservation; maturation; embling production

\section{Introduction}

In Finland, the increased planting of Norway spruce (Picea abies L. Karst.) seedlings and difficulties in seed production has resulted in intermittent shortages of regeneration material of a high breeding value [1]. One solution to this problem is to use vegetative propagation, e.g., somatic embryogenesis (SE), which was observed in Norway spruce for the first time in 1985 [2,3]. Vegetative propagation enables more efficient tree improvement e.g., by capturing non-additive genetic gain $[4,5]$.

Additionally, the cryopreservation of embryogenic tissue (ET) in liquid nitrogen (LN) enables long-term storage of regeneration material in its juvenile state [6-8]. Cryopreservation techniques are available for several conifer species, based on either applying cryoprotectant before freezing, or either on drying embryos or embryogenic tissues in different developmental stages [9-14]. Additionally, for Norway spruce, reliable cryopreservation protocols applicable for large number of samples have been developed $[8,15]$. As a result, acceptable recovery rates together with high morphological and genetic fidelity have been observed $[8,15]$.

The commercial scale production of conifer emblings, i.e., somatic embryo plants, has been achieved in Denmark, Ireland and France (Abies, Picea and Pinus species) and is being piloted in Sweden 
(Picea abies). Companies producing conifers (e.g., Pseudotsuga menziesii, Picea glauca engelmannii complex, Picea glauca (Moench) Voss and Picea sitchensis (Bong.) Carr., Pinus radiata D. Don, Pinus taeda L. and Pinus elliottii Engelm.) with SE for planting stock exists in North America and New Zealand [6,16,17].

The main reason limiting the commercial application of SE in forestry is the high cost of emblings compared to seedlings $[17,18]$. Several efforts to reduce costs have been made e.g., producing emblings as donor plants for rooted shoot cuttings, thus fragmenting the high cost of emblings to several hundred rooted shoot cuttings [17,19]. Despite all the efforts, emblings are still rather expensive compared to seedlings, which limits their deployment especially in Nordic conditions [20]. Additionally, the loss of genetic material during SE is a major challenge [21]. However, this could be mitigated by improving production methods in the post cryopreservation phases and in the laboratory-nursery interface [20-23].

Abscisic acid (ABA) is a relatively expensive plant hormone, widely used in conifer SE to promote embryo maturation [24]. It has a positive effect in promoting the maturation of embryogenic tissues, but it can also inhibit the germination and height growth of emblings for several growing seasons after exposure [7,25-27]. The type and amount of ABA concentration significantly affects the maturation results, and the optimal concentration varies between species and genotypes [27-29].

Similar, species and genotype specific, responses in embryo maturation have been reported when various amounts and types of polyethylene glycol has been added to the maturation medium in different conifer species [30-33]. Polyethylene glycol is added to the maturation media to reduce the moisture content of somatic embryos, thus increasing the content of the storage materials in later phases of maturation compared to ABA [31,32,34]. In Norway spruce, polyethylene glycol 4000 (PEG), when added to the maturation media, is known to increase the number of somatic embryos but is also known to have a negative effect on the later growth and development of the embryos $[25,35,36]$. PEG has also been found to speed up somatic embryo maturation by several weeks [31,36].

The aim of this work was to improve the efficiency of Norway spruce embling production in order to enable large scale testing of numerous SE lines. To achieve this we studied, (I) the effects of different levels of ABA and PEG in maturation media and the effect of an additional cryopreservation cycle on embryo production capacity; and (II) the effects of two different growing techniques on embling yield and early performance. Furthermore, the embryo production capacity and survival rate in the nursery were tested for a wide range of genotypes (712) originating from 12 full-sib families, with the aim to initiate field testing with rooted cuttings. This was done to improve the properties and yield of emblings (I and II) and to evaluate embling production schemes needed for large-scale field testing and variation among full-sib families affecting them (III).

\section{Materials and Methods}

\subsection{Origin of Embryogenic Lines}

The embryogenic lines used in this study were initiated in 2014 and 2015 from immature zygotic embryos of full-sibling families of progeny tested plus trees from Southern Finland. The medium and methods developed by Klimaszewska et al. [37], as described by Varis et al. [8] were used for culture establishment. Zygotic embryos without megametophytes, were placed on a modified Litvay's medium (mLM) containing half-strength macroelements [37,38], $10 \mu \mathrm{M}$ 2,4-dicholophenoxyacetic acid (2,4-D), and $5 \mu \mathrm{M}$ 6-benzyladenine (BA). The sucrose concentration of the medium was $1 \%(w / v)$ and the $\mathrm{pH}$ was adjusted to 5.8 prior to adding gellan gum $\left(4 \mathrm{~g} / \mathrm{L}\right.$, Phytagel ${ }^{\mathrm{TM}}$, Sigma-Aldrich, Saint Louis, MO, USA) and autoclaving. The cultures were kept in the dark (at $24^{\circ} \mathrm{C}$ ) for two to eight weeks without subculturing, until embryogenic tissue (ET) started to grow. Established ETs were subcultured bi-weekly, on a fresh Petri dish of the same medium.

Cryopreservation of ETs was done according to Varis et al. [8]. From each genotype one to four samples were cryopreserved right after initiation. Slowly growing ETs were not cryopreserved. The number of samples per genotype was kept low to increase the number of genotypes in cryostorage. 
For maturation in all experiments, from 150 to 200 milligrams of fresh embryogenic mass was weighed and absorbed on filter paper (Whatman \# 2), using a Buchner funnel as done by Varis et al. [8].

\subsection{Experiment I}

The effect of the ABA concentration on embryo production and plant viability was studied using three different trials (1, 2 and 3). In Trial 1, six continuously subcultured Norway spruce embryogenic lines from five families initiated in 2014 were matured in December 2015, and seven lines from four families initiated in 2015 were matured in February 2016. Each line was matured on six filter papers (Whatman \# 2) which were placed in petri dishes filled with $28 \mathrm{~mL}$ of LM-media containing 60 or $20 \mu \mathrm{M}$ ABA (Later referred to 60ABA and 20ABA), and three maturations of each treatment (Table 1). Filter papers on the latter media were moved to fresh media two times at one-week intervals at the beginning of maturation. Cotyledonary embryos with visible initial shoot and root meristems and at least four cotyledons were manually counted after eight weeks maturation in the dark at $24{ }^{\circ} \mathrm{C}$ room temperature, as was done in previous studies $[39,40]$.

Table 1. Schematic description of experiments and treatments used in different phases of SE production in Experiments I to III.

\begin{tabular}{|c|c|c|c|c|c|}
\hline Exp./Trial & Treatment & Maturation & Germination & $\begin{array}{l}\text { 1st Growing Period/Growing } \\
\text { Season }\end{array}$ & 2nd Growing Season \\
\hline $\mathrm{I} / 1 ; 2 ; 3$ & 60ABA & 8 weeks & & & \\
\hline $\mathrm{I} / 1$ & $3^{*} 20 \mathrm{ABA}$ & 8 weeks & & & \\
\hline $\mathrm{I} / 2$ & $60 \mathrm{ABA}+\mathrm{PEG}$ & 8 weeks & & & \\
\hline $\mathrm{I} / 2$ & $30 \mathrm{ABA}+\mathrm{PEG}$ & 8 weeks & & & \\
\hline $\mathrm{I} / 2 ; 3$ & $30 \mathrm{ABA}$ & 8 weeks & & & \\
\hline \multirow{6}{*}{ II } & GT-I & $\begin{array}{c}8 \text { weeks } \\
60 \mu \mathrm{M}\end{array}$ & $\begin{array}{l}\text { 18:6 Day-night } \\
1 \text { week }^{(1)}\end{array}$ & \multirow{6}{*}{$\begin{array}{c}\text { Transplanted to Miniplugs } \\
\text { Controlled environment } \\
\text { Transplanted to Plantek } 81 \mathrm{f} \\
\text { Winterized and cold stored } \\
\text { Transplanted to Plantek } 81 \mathrm{f} \\
\text { Nursery greenhouse in } \\
\text { March } 2017 \\
\text { Grown outside since June } 2017\end{array}$} & \multirow[t]{6}{*}{$\begin{array}{c}\text { Grown outside since } \\
\text { June } 2017\end{array}$} \\
\hline & & $30 \mu \mathrm{M}$ ABA & & & \\
\hline & \multirow{4}{*}{ GT-II } & & & & \\
\hline & & 8 weeks & 18:6 Day-night & & \\
\hline & & $60 \mu \mathrm{M}$ & & & \\
\hline & & $30 \mu \mathrm{M}$ ABA & & & \\
\hline \multirow{10}{*}{ III } & Thawing lots $\mathrm{A}$ to $\mathrm{D}$ & $\begin{array}{c}8 \text { weeks } \\
60 \mu \mathrm{M} \text { ABA }\end{array}$ & $\begin{array}{l}\text { 18:6 Day-night } \\
1 \text { week }^{(1)}\end{array}$ & $\begin{array}{l}\text { Transplanted to Miniplugs } \\
\text { Controlled environment }\end{array}$ & \multirow[t]{10}{*}{$\begin{array}{c}\text { Grown outside since } \\
\text { June } 2017\end{array}$} \\
\hline & & & & Winterized and cold stored & \\
\hline & Thawing lot E & 8 weeks & 18:6 Day-night & Transplanted to Miniplugs & \\
\hline & & $30 \mu \mathrm{M}$ ABA & 1 week $^{(1)}$ & Controlled environment & \\
\hline & & & & Transplanted to Plantek 81f in & \\
\hline & \multirow{5}{*}{ Thawing lot $\mathrm{F}$} & & & March 2017 & \\
\hline & & & & Grown outside since June 2017 & \\
\hline & & 8 weeks & 18:6 Day-night & tek $81 \mathrm{lt}$ & \\
\hline & & $30 \mu \mathrm{M}$ ABA & 1 week $^{(1)}$ & $\begin{array}{l}\text { Nursery greennouse in } \\
\text { March } 2017\end{array}$ & \\
\hline & & & & Grown outside since June 2017 & \\
\hline
\end{tabular}

In Experiment I, the effect of different concentrations/combinations of abscisic acid (ABA) and polyethylene glycol 4000 (PEG) on the yield of cotyledonary embryos was tested. $3^{*}$ means a transfer of ET twice to fresh media. In Experiment II, two ex vitro growing techniques for emblings were tested (GT-I and GT-II). In Experiment III, large number of samples from 12 full-sib families was thawed from cryopreservation in lots A to F, to produce emblings (cutting donors) for clone testing. (1) three days in five $\mu \mathrm{mol} / \mathrm{m}^{-2} / \mathrm{s}^{-1}$, two days in $50 \mu \mathrm{mol} / \mathrm{m}^{-2} / \mathrm{s}^{-1}$ and two days in $150 \mu \mathrm{mol} / \mathrm{m}^{-2} / \mathrm{s}^{-1}$.

Trial 2 consisted of seven genotypes (from different full-sib families) which were matured in May 2016. Two of the lines were initiated in 2015 and maintained in a subculture. Five lines initiated in 2014 were thawed from LN. Four different ABA $(60$ and $30 \mu \mathrm{M})$ and PEG $(4.75 \%$ concentration in media) combinations were used in mLM-media (later referred to 60ABA, 30ABA, 60ABA + PEG and $30 \mathrm{ABA}+\mathrm{PEG})($ Table 1). The filters were kept in the original petri dishes for eight weeks under the same conditions as in Trial 1, after which cotyledonary embryos were counted.

Trial 3 consisted of 120 cryopreserved genotypes from 12 families (10 genotypes per family), which were thawed from LN and matured using LM media with two different ABA concentrations (Table 1). The first lot of 120 genotypes was thawed and matured in 2016. From these genotypes, 
samples were cryopreserved again and one sample per genotype was thawed and matured in 2017. From the first lot, samples from 65 genotypes were matured on media containing $60 \mu \mathrm{M}$ of $\mathrm{ABA}$, and 55 genotypes were matured on media with a $30 \mu \mathrm{M}$ ABA concentration. In the second lot, all 120 genotypes were matured on media containing $30 \mu \mathrm{M}$ ABA. The filters were kept in the original Petri dishes for eight weeks in the same conditions as Trial 1, after which cotyledonary embryos were counted.

\subsection{Experiment II}

Two different growing techniques (later referred to GT-I and GT-II) in a nursery were evaluated by germinating cotyledonary embryos from 18 genotypes ( 9 families) according to the $1 \mathrm{w}$-filter protocol described by Tikkinen et al. [23]. In short: cotyledonary embryos, cold stored at $+3{ }^{\circ} \mathrm{C}$ (for at least four weeks in a large refrigerator unit) on the same filter papers in Petri dishes where the maturation was carried out, were germinated one-week in vitro under LED (Light emitting diode) lights (at a temperature from 20 to $23{ }^{\circ} \mathrm{C}$ inside the Petri dishes). The emblings were transplanted to a peat-based growth media after germination in vitro, using the 'pricking out' method as described by Landis et al. [23,41], in which forceps were used to transfer the emblings and to place them in peat. Peat was gently compressed around the embling to provide sufficient edaphic conditions for developing roots, as demonstrated by Landis et al. [23,41].

In GT-I, 36 emblings from each genotype were transplanted in small containers (Preforma 126/JIF, ViVi Pak, ViVi, Burgh Haamstede, Netherlands) with 126 plugs per container (plug volume $3.4 \mathrm{~mL}$ ) (Miniplugs), and grown in a controlled environment for 50 days, until the temperature sum reached 1300 degree days (d.d.) (later referred to as the growing period). The controlled environment refers to a growth room, where the light period, temperature and humidity were adjusted to obey suggested levels for the different stages of growth of Norway spruce seedlings [42]. After this artificial growing season, the emblings were transplanted into Plantek $81 \mathrm{f}$ containers, winterized and cold stored in a large cooler unit. After cold storage the emblings were transferred outside together with a large lot of seedlings (Table 1).

In GT-II, 81 emblings from each genotype were transplanted straight into Plantek 81f containers (81 separate ventilated compartments of $85 \mathrm{~cm}^{3}$ size) and were grown in a greenhouse as described by Tikkinen et al. [23]. These emblings were grown together with the emblings from thawing lots A to D of Experiment III (Table 1).

\subsection{Experiment III}

To initiate the field testing of SE-lines, emblings were produced for donor plants for shoot cuttings. This was done with cryopreserved genotypes from 12 full-sib families, initiated in 2014 (Table 2). The aim was to produce emblings from 20 genotypes from each full-sib family to initiate field testing with rooted shoot cuttings.

ETs were thawed from 712 genotypes at six different times, in thawing lots A to F. Thawings were carried out during 2016 (A to E) and 2017 (F) (Table 2). ETs were thawed, subcultured bi-weekly, cryopreserved again and matured (three Petri dishes each) in a five or ten weeks production cycle [8,37,38]. If the ET did not proliferate enough for cryopreservation and maturation in ten weeks it was discarded.

The ETs were cryopreserved again to increase the number of samples from each genotype for future use. Cryopreservation was prioritized, so that maturation was delayed for five weeks, if necessary. In the cases of poorly proliferating ETs, they were matured first and cryopreserved only if enough embryogenic tissue was available after 10 weeks of proliferation. This was done to increase the number of genotypes available for field testing. 
Table 2. Description of material included in Experiment III.

\begin{tabular}{|c|c|c|c|c|c|c|c|c|c|c|}
\hline Crossing & Explants & Initiated & Cryostored & Thawing & Thawed & Cryo + Maturation & E/gFW & Over $200 \mathrm{E} / \mathrm{gFW}$ & Surv. $\% \mathrm{~A}$ to $\mathrm{D}$ & Surv. \% E to $\mathrm{F}$ \\
\hline $\mathrm{E} 1551 \times \mathrm{E} 2229$ & 99 & 67 & 61 & III, IV and VI & 48 & 45 & $94( \pm 13)$ & 7 & $28( \pm 2)$ & $72( \pm 2)$ \\
\hline $\mathrm{E} 162 \times \mathrm{E} 81$ & 200 & 101 & 66 & II and VI & 48 & 42 & $89( \pm 12)$ & 5 & $14( \pm 2)$ & $87( \pm 2)$ \\
\hline $\mathrm{E} 18 \times \mathrm{E} 436$ & 200 & 133 & 127 & III and VI & 47 & 30 & $110( \pm 18)$ & 6 & $62( \pm 2)$ & $85( \pm 2)$ \\
\hline E207 $\times$ E1373 & 200 & 145 & 140 & III, IV and VI & 50 & 36 & $81( \pm 11)$ & 3 & $54( \pm 2)$ & $70( \pm 5)$ \\
\hline E207 × E252 & 200 & 60 & 52 & II, IV and VI & 51 & 43 & $124( \pm 14)$ & 6 & $30( \pm 2)$ & $78( \pm 2)$ \\
\hline $\mathrm{E} 2105 \mathrm{c} \times \mathrm{E} 2283$ & 200 & 114 & 98 & II, IV and VI & 50 & 45 & $40( \pm 9)$ & 1 & $14( \pm 2)$ & $66( \pm 5)$ \\
\hline $\mathrm{E} 212 \times \mathrm{E} 54$ & 200 & 127 & 92 & $\mathrm{I}, \mathrm{IV}$ and $\mathrm{V}$ & 92 & 61 & $45( \pm 7)$ & 2 & $14( \pm 2)$ & $80( \pm 2)$ \\
\hline $\mathrm{E} 242 \times \mathrm{E} 222$ & 400 & 187 & 106 & I, IV, V and VI & 106 & 49 & $36( \pm 7)$ & 2 & $10( \pm 2)$ & $82( \pm 2)$ \\
\hline $\mathrm{E} 46 \times \mathrm{E} 3222$ & 400 & 244 & 209 & III and VI & 78 & 53 & $89( \pm 12)$ & 5 & $25( \pm 2)$ & $88( \pm 2)$ \\
\hline $\mathrm{E} 462 \times \mathrm{E} 64$ & 200 & 160 & 137 & I and VI & 48 & 41 & $81( \pm 13)$ & 5 & $54( \pm 2)$ & $81( \pm 1)$ \\
\hline E799 × E1366 & 45 & 42 & 36 & II and IV & 34 & 32 & $144( \pm 21)$ & 7 & $24( \pm 2)$ & \\
\hline $\mathrm{E} 9 \times \mathrm{E} 3231$ & 400 & 132 & 123 & I and VI & 60 & 52 & $68( \pm 10)$ & 5 & $5( \pm 1)$ & $71( \pm 2)$ \\
\hline Overall & 2744 & 1512 & 1247 & I to VI & 712 & 529 & $79( \pm 4)$ & 54 & $30( \pm 1)$ & $80( \pm 1)$ \\
\hline
\end{tabular}

Number of explants, genotypes initiated and cryopreserved in 2014. Thawing lot, number of genotypes thawed, cryopreserved again and matured. Yield of cotyledonary embryos (E/gFM)

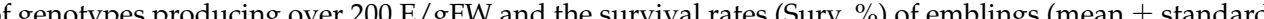

error) from different crossings from thawing lots $\mathrm{A}$ to $\mathrm{D}$ and $\mathrm{E}$ to $\mathrm{F}$, in Experiment III. 


\subsubsection{Thawing, Proliferation Maturation and Germination}

After eight weeks of maturation under the same conditions as Experiment I, cotyledonary embryos were manually counted and cold stored on filter papers, as described by Tikkinen et al. [23]. In the case of thawing lot $\mathrm{B}$, the maturation dishes were moved to cold storage before counting. The maturation medium contained $60 \mu \mathrm{M} \mathrm{ABA}$, in thawing lots $\mathrm{A}$ to $\mathrm{D}$, and $30 \mu \mathrm{M} \mathrm{ABA}$ in thawing lots $\mathrm{E}$ and $\mathrm{F}$ (Table 1). Maturation media was changed between thawing lots $D$ and $E$, because of the higher yield of cotyledonary embryos in media with a lowered ABA concentration observed in Experiment I.

\subsubsection{Embling Production}

A one-week in vitro germination protocol was used in all cases following the methods described by Tikkinen et al. [23]. Because of limited resources, e.g., work force and growing space, for thawing lots A to E, only up to 36 cotyledonary embryos from each genotype were selected for cultivation depending on the availability of cotyledonary embryos. The cotyledonary embryos were grown as in GT-1 (Table 1). The emblings from thawing lot E were grown according to GT-I, with the exception that the emblings were transferred straight to the nursery in spring 2017, while they were still growing height (Table 1).

Germinated emblings from thawing lot $\mathrm{F}$ were grown as in GT-II (Table 1). From thawing lots E and $\mathrm{F}$, up to 81 cotyledonary embryos were selected for cultivation depending on the availability of cotyledonary embryos.

\subsection{Measurements and Data Analysis}

Cotyledonary embryos were counted and the embryo productivity was calculated per one gram of fresh cell mass (E/gFM) in all experiments. Mean values are presented with their standard errors $( \pm)$. All measurements and inventory results were analyzed using the IBM SPSS Statistics 22 software package (International Business Machines Corporation, Ammonk, NY, USA). The level of confidence used was $5 \%$.

In Experiment I, nonparametric tests were used because normal distribution could not be assumed. In Trials 1 and 3 of Experiment I, differences between treatments were analyzed with Mann-Whitney U-test. In Trial 2 of Experiment I, the Kruskal-Wallis test (one-way ANOVA on ranks) was used to analyze differences between treatments.

To compare the two growing techniques in Experiment II, the survival of the emblings was inventoried from GT-I after the first growing period in a controlled environment, i.e., before cold storage. The survival and height measurements for the 2017 growing season, were obtained for both growing techniques. Logistic regression was used to examine the differences in survival between growing techniques, after the first growing period and after the growing season of 2017. A non-parametric test (Mann-Whitney U) was used to test the differences in embling height between the two growing techniques, because a normal distribution could not be assumed.

In Experiment III, the differences in embling survival between families were examined with logistic regression after the first growing period and after the growing season of 2017. A crossing covariate was used to investigate a possible parental effect. A thawing covariate was used to distinguish differences between different thawing lots. Among thawing lots, variation occurs in the date of thawing, the ABA concentration in the maturation media, the growing method and the lenght of the cold storage period. The effect of the thawing lot had no effect on the percentage of cases predicted correctly and was left out from the final models. The effect of location inside the containers was studied by using row and column covariates, which defined the location of a single embling inside a container. This effect was significant, but explained only $0.1 \%$ of the correctly predicted cases; hence row and column covariates were excluded from the final models. Embryo production between full-sib families was analyzed with Kruskal-Wallis and Mann-Whitney U nonparametric tests, because normal distributions could not be assumed. 


\section{Results}

\subsection{Effect of ABA Concentration and PEG in the Maturation Media}

In Trial 1, with the first group of genotypes (Experiment 1), the mean yield of cotyledonary embryos was $80 \pm 23 \mathrm{E} / \mathrm{gFM}$ when the media contained $60 \mu \mathrm{M} \mathrm{ABA}$, and $185 \pm 24 \mathrm{E} / \mathrm{gFM}$ when the ETs on filters were twice transferred to fresh media containing $20 \mu \mathrm{M}$ ABA (Figure 1). Reducing the ABA concentration in the maturation media enhanced embryo production by $131 \%(p<0.001)$.

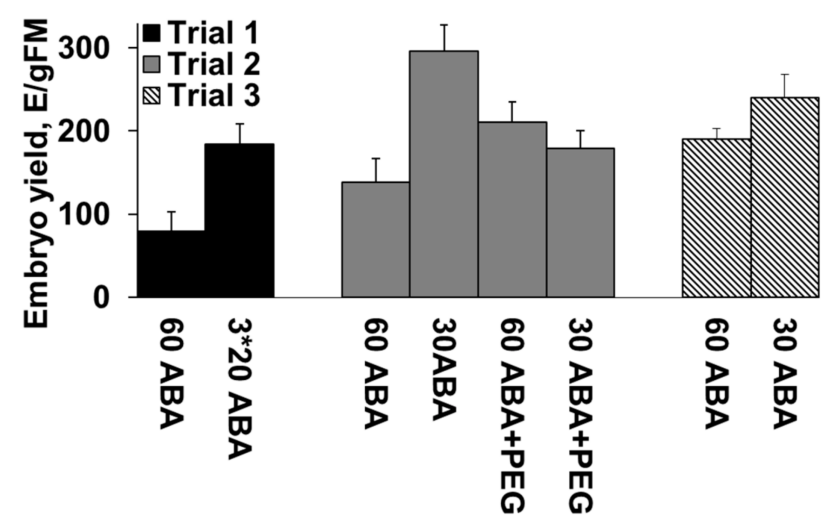

Figure 1. Yield of cotyledonary embryos in different treatments in three Trials in Experiment I. Mean values are presented with standard error bars. In Trial 3, values are presented for genotypes for which maturation with both treatments was available.

In Trial 2, reducing the amount of ABA enhanced the productivity even though the cell mass was not transferred to fresh media. The mean productivity on $30 \mu \mathrm{M}$ ABA was $296 \pm 31 \mathrm{E} / \mathrm{gFM}$ while on $60 \mu \mathrm{M}$ $\mathrm{ABA}$ it was $139 \pm 28 \mathrm{E} / \mathrm{gFM}$, with the increase being $113 \%(p=0.001)$ (Figure 1). Adding PEG increased the productivity only when combined with $60 \mu \mathrm{M}$ ABA $(211 \pm 24 \mathrm{E} / \mathrm{gFM})$. With $30 \mu \mathrm{M}$ ABA the number of cotyledonary embryos decreased to $179 \pm 22 \mathrm{E} / \mathrm{gFM}$ when PEG was included in the media (Figure 1).

In Trial 3, the average yield of cotyledonary embryos among genotypes in the first lot was $180 \pm 9 \mathrm{E} / \mathrm{gFM}$. For the 65 genotypes matured on $60 \mu \mathrm{M}$ ABA, the average embryo yield was $191 \pm 1 \mathrm{E} / \mathrm{gFM}$. For the 55 genotypes matured on $30 \mu \mathrm{M}$ ABA, the embryo yield was $166 \pm 14 \mathrm{E} / \mathrm{gFM}$. In the second lot, following cryopreservation, with $30 \mu \mathrm{M}$ ABA used in the maturation media for all genotypes, the overall embryo yield was $206 \pm 19 \mathrm{E} / \mathrm{gFM}$. For the genotypes matured with 60 or $30 \mu \mathrm{M}$ ABA in the first lot, the average embryo yields in the second lot were $240 \pm 28 \mathrm{E} / \mathrm{gFM}$ and $167 \pm 24 \mathrm{E} / \mathrm{gFM}$, respectively. In the second lot, 116 genotypes were successfully regenerated from cryostorage and 114 were matured. No significant change in the average embryo production was found between lots when separately examining the genotypes matured on media containing $30 \mu \mathrm{M}$ ABA in both lots, or between genotypes matured with $60 \mu \mathrm{M}$ ABA in the first lot.

\subsection{In Vitro Germination, Survival and Height Growth}

In Experiment II, all selected cotyledonary embryos germinated and were transplanted ex vitro in both growing techniques. In GT-I, the average survival rate was $93 \pm 1 \%$, after the growing period, before cold storage. After cold storage and the growing season of 2017 in the nursery, the average survival rate and height were $53 \pm 2 \%$ and $5.8 \pm 0.3 \mathrm{~cm}$, respectively. In GT-II, the average survival rate and height of the emblings after the first growing season (2017) in the nursery were $77 \pm 1 \%$ and $10.9 \pm 0.2 \mathrm{~cm}$, respectively.

The difference in the embling survival rates between GT-I (after first growing period) and GT-II (after the first growing season of 2017) was significant $(p<0.001)$ (Table 3). The survival and height of the emblings obtained from different growing techniques varied after the growing season of 2017 $(p<0.001$, in both) (Table 3). 
Table 3. Logistic regression models used for analyzing binary response (living or dead) in different growing techniques (GT-I and GT-II), after first growing season in the nursery or artificial growing season in growth room (GP1) and after the growing season of 2017 in the nursery, for Experiments II and III.

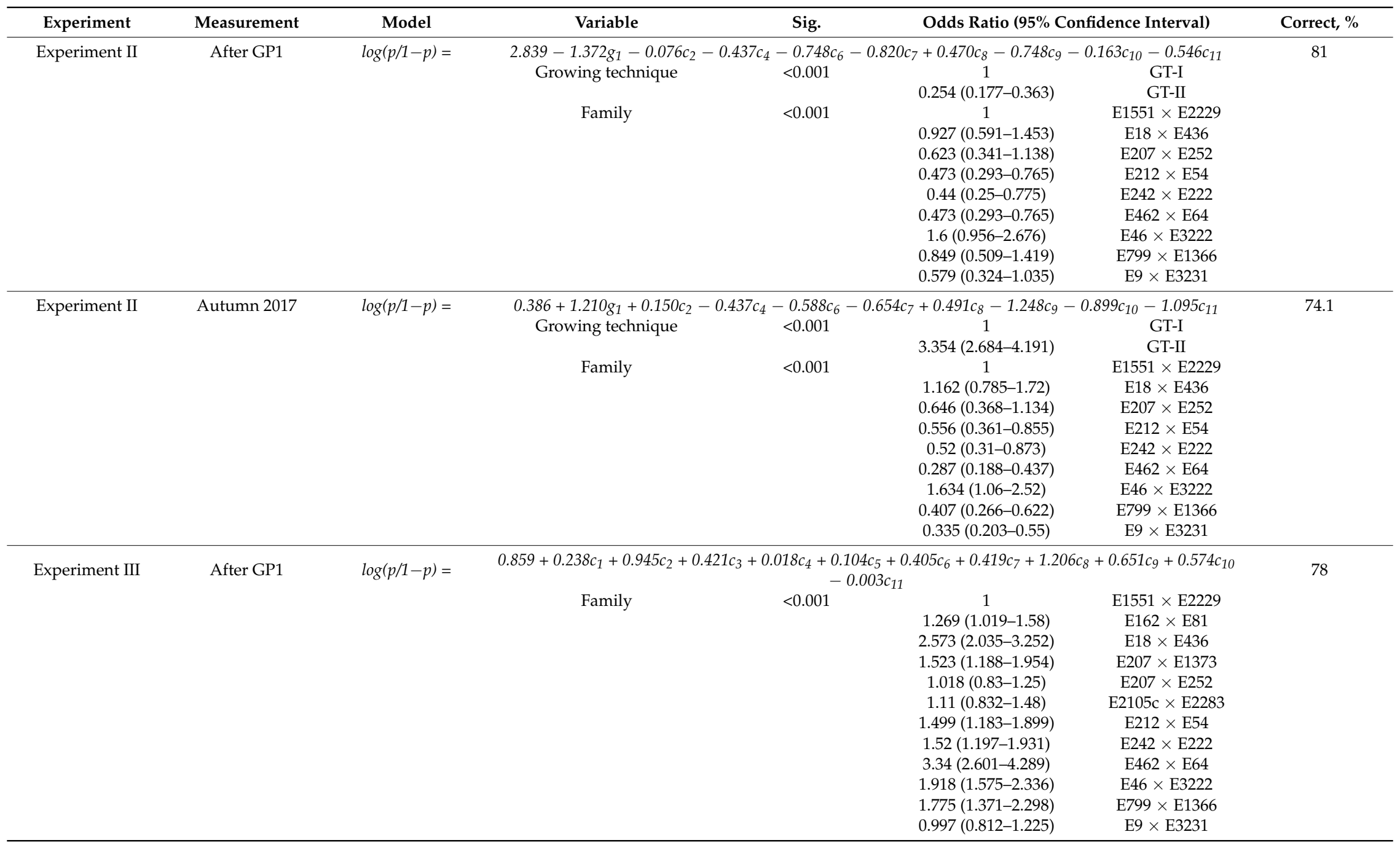


Table 3. Cont

\begin{tabular}{|c|c|c|c|c|c|c|c|}
\hline Experiment & Measurement & Model & Variable & Sig. & \multicolumn{2}{|c|}{ Odds Ratio (95\% Confidence Interval) } & Correct, $\%$ \\
\hline \multirow[t]{19}{*}{ Experiment III } & \multirow[t]{19}{*}{ Autumn 2017} & \multirow[t]{19}{*}{$\log (p / 1-p)=$} & \multicolumn{4}{|c|}{$\begin{array}{c}-2.652+0.613 b_{1}+1.186 b_{2}+0.915 b_{3}+3.753 b_{4}+3.334 b_{5}+0.632 c_{1}+1.186 c_{2}+0.886 c_{3}+0.912 c_{4}+ \\
0.108 c_{5}+0.365 c_{6}+0.401 c_{7}+1.494 c_{8}+0.831 c_{9}+0.840 c_{10}+0.126 c_{11}\end{array}$} & 76.5 \\
\hline & & & \multirow[t]{6}{*}{ Thawing } & $<0.001$ & 1 & $\mathrm{~A}$ & \\
\hline & & & & & $1.846(1.326-2.571)$ & B & \\
\hline & & & & & $6.66(4.935-8.988)$ & $\mathrm{C}$ & \\
\hline & & & & & 2.497 (1.714-3.638) & D & \\
\hline & & & & & 42.655 (29.934-60.782) & E & \\
\hline & & & & & $28.049(21.653-36.334)$ & $\mathrm{F}$ & \\
\hline & & & \multirow{12}{*}{ Family } & $<0.001$ & 1 & E1551 × E2229 & \\
\hline & & & & & $1.881(1.427-2.479)$ & $\mathrm{E} 162 \times \mathrm{E} 81$ & \\
\hline & & & & & 3.275 (2.659-4.034) & $\mathrm{E} 18 \times \mathrm{E} 436$ & \\
\hline & & & & & $2.425(1.931-3.046)$ & E207 × E1373 & \\
\hline & & & & & $2.49(1.907-3.25)$ & E207 × E252 & \\
\hline & & & & & $1.114(0.776-1.601)$ & $\mathrm{E} 2105 \mathrm{c} \times \mathrm{E} 2283$ & \\
\hline & & & & & $1.441(0.973-2.135)$ & $\mathrm{E} 212 \times \mathrm{E} 54$ & \\
\hline & & & & & $1.493(1.049-2.123)$ & $\mathrm{E} 242 \times \mathrm{E} 222$ & \\
\hline & & & & & $4.456(3.266-6.08)$ & E462 × E64 & \\
\hline & & & & & $2.297(1.905-2.769)$ & $\mathrm{E} 46 \times \mathrm{E} 3222$ & \\
\hline & & & & & $2.316(1.659-3.232)$ & E799 × E1366 & \\
\hline & & & & & $1.134(0.88-1.462)$ & E9 × E3231 & \\
\hline
\end{tabular}

In the models g1 is a design variable for growing technique II, c1 to c11 are design variables for full-sib families (Family) and b1 to b5 are design variables for thawing lots (Thawing). 


\subsection{Donor Plant Production}

In Experiment III, 76\% (51\% to 94\% variation among full-sib families) of the thawed genotypes produced enough ET to be matured. Cotyledonary embryos were produced from $67 \%$ of the thawed genotypes, varying from $43 \%$ to $91 \%$ of the thawed genotypes among the full-sib families. The average yield of cotyledonary embryos was $79 \pm 4 \mathrm{E} / \mathrm{gFW}$ (Table 2).

In thawing lots $A$ to $D$, the average yield of cotyledonary embryos was $80 \pm 4 \mathrm{E} / \mathrm{gFW}$. The embryo yield varied between families $(p<0.001)$. In thawing lot $\mathrm{E}$, in which all the remaining cryopreserved genotypes were thawed from two full-sib families with the lowest number of genotypes producing cotyledonary embryos, on average $46 \pm 9 \mathrm{E} / \mathrm{gFW}$ were produced. In thawing lot $\mathrm{F}$, the mean yield of cotyledonary embryos was $92 \pm 10 \mathrm{E} / \mathrm{gFW}$. In thawing lots $\mathrm{E}$ and F, the embryo yield varied among full-sib families $(p=0.002)$.

Overall, 12,910 germinated emblings from thawing lots A to F were transplanted into peat-based growth media. From thawing lots A to D, 8904 germinated emblings from 340 genotypes (varying from 21 to 34 genotypes per family) were transplanted into small growing containers. From thawing lots $\mathrm{E}$ and $\mathrm{F}$, 4013 emblings were transplanted straight into Plantek 81f containers. In thawing lots A to F, the embling survival rate after the first growing period or season varied between full-sib families $(p<0.001)$.

From thawing lots A to D, 3837 growing emblings (43\%) were recorded after the growing period, varying from 21 to 34 genotypes per family. After cold storage and the 2017 growing season in the nursery, only 1481 (17\% overall) of the transplanted emblings from 12 to 28 genotypes per family were alive.

In thawing lots $\mathrm{E}$ and F, 4006 emblings from 127 genotypes, from two to 24 genotypes per family, were transplanted into Plantek 81f containers in May 2017. In autumn 2017, the number of vital emblings was 3196 (80\% survival), consisting of 121 genotypes, from two to 23 genotypes per family.

In October 2017, a total of 4677 plants were vital from 356 genotypes (50\% of all thawed genotypes), from 42 to 18 genotypes among full-sib families. The embling survival rate varied between thawing lots and full-sib families ( $p<0.001$, in both). When the inventories from thawing lots A to D after the first growing period were combined with the inventory from thawing lots $\mathrm{E}$ and $\mathrm{F}$ after the 2017 growing season, the average survival rate of transplanted emblings was $54 \%$. Survival varied from $50 \%$ to $89 \%$ among full-sib families. Numbers include emblings from 439 genotypes (62\% of the thawed genotypes) varying from 26 to 48 genotypes between full-sib families.

\section{Discussion}

The embryo yield increased significantly in different groups of genotypes when the ABA concentration in the maturation media was reduced. The increase in embryo yield was over two-fold in Trials 1 and 2 of Experiment I when the reduced amount of ABA was compared to the control $60 \mu \mathrm{M}$ ABA treatment. Adding PEG to the semi-solid maturation media increased the embryo yield when compared to $60 \mu \mathrm{M}$ ABA content. However, the highest embryo yield was gained without PEG. Using maturation media with $20 \mu \mathrm{M}$ ABA and subculturing embryogenic tissues with filter paper resulted in the highest embryo yield. However, the subculturing is labour intensive when used with a large number of samples. For this reason, a maturation protocol, including media containing $30 \mu \mathrm{M}$ ABA without subculturing was introduced as standard protocol.

When the ABA content in the maturation media was lowered, the average embryo production increased slightly among a large number of samples in a group of different genotypes (Trial 3 in Experiment I) which had been cryopreserved and thawed at least once before. This happened although more variation between individual genotypes was observed. Additionally, in previous studies, cryopreservation has not systematically reduced embryo production (see e.g., [8,25]). The loss of genetic material by cryopreservation accounted for $5 \%$ of the thawed genotypes distributed between five full-sib families. The possible loss of genotypes due to cryopreservation is a potential risk when a small number of samples are initially cryopreserved (see e.g., [8,25]). 
The highest survival rate was recorded when germinated emblings were transplanted straight into the nursery (GT-II), although the average survival rate was significantly higher among emblings grown in small containers for the first growing period (GT-I) before cold storage. The decline in embling survival among emblings in GT-I was most likely due to improper cold storage conditions and fungicide treatments, which resulted in a severe infestation of mold (possibly Botrytis sp.).

The plants grown in treatment GT-II were significantly taller, although they were grown for one growing period less. This is most likely due to insufficient lighting in the growth room in treatment GT-I combined with the damage caused to initial meristems during cold storage. In treatment GT-I, the growth room light intensity in the photosynthetically active radiation (PAR) region in full light was set to $150 \mu \mathrm{mol} / \mathrm{m}^{-2} / \mathrm{s}^{-1}$. In the greenhouse, emblings were subjected to sunlight filtered through the plastic outer wall of the greenhouse. The suggested minimum light intensity to support height growth and prevent premature terminal bud formation on seedlings is $250 \mu \mathrm{mol} / \mathrm{m}^{-2} / \mathrm{s}^{-1}$ according to Landis et al. [41,42]. Emblings survived well in greenhouse conditions after one-week in vitro germination in treatment GT-II. This implies that a higher light intensity is not harmful for small emblings, as long as the air temperature is favourable. This was also observed previously by Tikkinen et al. [23].

Growing emblings in small containers in artificial conditions is plausible, although special attention needs to be paid to the cold storage conditions, similar to seedlings. Improvements in environmental control are still needed to match the properties of the emblings or seedlings obtained from conventional nurseries. Although, growing space can be saved by using small containers, the method requires additional labour and supplies (i.e., containers, substrate etc.) compared to the method where emblings are transplanted straight into the nursery (see e.g., [23,41]). Additionally, in Nordic conditions supplementary lighting is necessary during a short photoperiod. All the previous matters have an effect on the cost of the emblings. A detailed cost analysis is needed to define the threshold for embling vigor in containers, to determine whether using small containers is profitable.

The embling survival of $77 \%$ for cotyledonary embryos selected for in vitro germination is close to the germination and early vigour percentages of unimproved Norway spruce seeds and seedlings reported in earlier studies (see e.g., [43]). The observed mean height of $10.9 \mathrm{~cm}$ indicates that the emblings will reach sufficient height standards for planting during the second growing season. By selecting well acclimatizing genotypes for production, survival can be further increased, as suggested by Tikkinen et al. [23].

Genotypes with a high embryo production capacity (over $200 \mathrm{E} / \mathrm{gFW}$, with lowered ABA content) were found, and vigorous emblings were successfully produced from several genotypes from all full-sib families (Figure 1; Table 2). Not all of the cryostored genotypes from the families used were tested, although the number of samples was fairly large varying from 34 to 106 per family. Högberg [44] found that the loss of genotypes during the overall SE process can be vast. According to our results, genotypes with a good embryo production capacity can be found in all families. We thawed a sample of $57 \%$ of the 1247 cryopreserved genotypes, representing 12 full-sib families. With the current rates of genotypes successfully initiated (55\%) and cryopreserved (45\%) of the total number of explants (2744) from selected families, the sample of 712 thawed genotypes accounts for 1292 to 1567 explants (Table 2). In the autumn of 2017, vital emblings were recorded from 356 genotypes, i.e., $23 \%$ to $28 \%$ of the estimated explants. Without the loss of emblings due to improper storage, emblings from $28 \%$ to $34 \%$ of the estimated explants could have been obtained. These genotypes could possibly be used for the large-scale propagation of emblings.

Plant loss during the cold storage of emblings from thawing lots A to D was severe, as $61 \%$ of emblings which had formed initial buds after the first growing period were lost during cold storage after the first growing period. This was most likely due to the same reasons as those found in the GT-I Experiment II, as the emblings were kept in the same cold storage unit. It is unacceptable to lose emblings at this magnitude after the most critical steps of embling production have been endured. 
Hence, controlling the storage conditions and applying chemical treatments against mold must not be overlooked.

The genetic entry and early phases in the SE process, set limits for the later phases of the production (see e.g., [20]). Our results show, that the final output, e.g., the yield and quality of the emblings, together with the genetic diversity of the output of the SE process can be significantly improved by developing the later phases of production.

When a maturation media with a lower ABA concentration was used, the embryo yield increased to such an extent that transplanting germinated emblings in vitro straight into the nursery may be considered the best growing method. This is in line with the findings of [23,45]. Clone testing can be initiated significantly faster by using 12 emblings as cutting donors from each genotype, compared to using seedlings as cutting donors (see e.g., [46]). To succeed, on average 16 cotyledonary embryos need to be germinated for one-week in vitro and transplanted straight into a nursery for each genotype, with a $77 \%$ survival rate (Experiment II).

To initiate clone testing directly with emblings, 24 to 32 ramets per genotype are needed in the Finnish spruce breeding programme [47]. To produce this number of emblings, an average of 32 to 42 cotyledonary embryos are needed, with an expected survival rate of $77 \%$ from Experiment II. From the poorest family in Experiment III, 37 to 49 cotyledonary embryos are needed with an expected survival rate of $77 \%$.

From the current data, covering 12 families in Experiment III, 394 genotypes reached the embryo production limit of 16 cotyledonary embryos from three maturation dishes ( $25 \%$ to $30 \%$ of estimated explants, 27 genotypes in the poorest family) and 336 produced over 32 cotyledonary embryos from three maturation dishes ( $21 \%$ to $26 \%$ of the estimated explants, 17 genotypes in poorest family). The current results indicate that large-scale field testing can be initiated from cryostored ETs with the current production protocol. Protocol includes short maturation on semisolid media containing $30 \mu \mathrm{M}$ ABA, cold storing cotyledonary embryos on maturation dishes, and transplanting emblings into a nursery after one-week in vitro germination.

\section{Conclusions}

Reducing the ABA concentration in the maturation media increased the yield of cotyledonary embryos. When combined with state-of-the-art embryo storage and in vitro germination protocols, emblings can be grown and large-scale field testing can be initiated with current nursery protocols with material from a wide genetic background. Intensive planning, considering production in the laboratory and in the nursery, is essential to achieve good results. Despite large variations in embryo/embling production, genotypes with good production properties were found in all families in this study. Furthermore, automation is needed to further increase the production numbers and cost effectiveness, especially in the laboratory-nursery interface, where the embryos and emblings are individually handled.

Author Contributions: M.T. had the main responsibility for the planning and experimental set up for the study (Experiments I (Trial 3), II, III) and had the main responsibility for data measurements and analysis, and the writing of the manuscript. S.V. had the main responsibility for planning, the experimental set up, taking measurements and data analysis of Experiment I (Trials 1 and 2), and participated in the writing of the manuscript. T.A. participated in the planning of the experimental set up for the study in all experiments (including data measurements and analyses) and in the writing of the manuscript.

Funding: The writers would like to thank the European Regional Development Fund, South Savo Regional Council, Savonlinna Business Services Ltd. and Savonlinna municipality for funding this research.

Conflicts of Interest: The authors declare no conflict of interest. 


\section{References}

1. Haapanen, M.; Leinonen, H.; Leinonen, K. Männyn ja kuusen siemenviljelyssiemenen taimitarhakäytön kehitys 2006-2016: Alueellinen tarkastelu. Metsätieteen Aikakauskirja 2017. [CrossRef]

2. Chalupa, V. Somatic embryogenesis and plantlet regeneration from cultured immature and mature embryos of Picea abies (L.) Karst. Commun. Inst. For. Czech Repub. 1985, 14, 57-63.

3. Hakman, I.; Fowke, L.C.; von Arnold, S.; Eriksson, T. The development of somatic embryos in tissue cultures initiated from immature embryos of Picea abies (Norway spruce). Plant Sci. 1985, 38, 53-59. [CrossRef]

4. Bonga, J.M. Conifer clonal propagation in tree improvement programs. In Vegetative Propagation of Forest Trees; Park, Y.-S., Bonga, J.M., Moon, H.-K., Eds.; Korea Forest Research Institute: Seoul, Korea, 2016; pp. 3-31.

5. Burdon, R.D.; Aimers-Halliday, Y.J. Risk management for clonal forestry with Pinus radiate-Analysis and review 1: Strategic issues and risk spread. N. Z. J. For. Sci. 2003, 33, 156-180.

6. Grossnickle, S.C.; Cyr, D.; Polonenko, D.R. Somatic embryogenesis tissue culture for the propagation of conifer seedlings: A technology comes of age. Tree Plant. Notes 1996, 47, 48-57.

7. Högberg, K.-A.; Bozhkov, P.V.; Grönroos, R.; von Arnold, S. Critical Factors Affecting Ex Vitro Performance of Somatic Embryo Plants of Picea abies. Scand. J. For. Res. 2001, 16, 295-304. [CrossRef]

8. Varis, S.; Ahola, S.; Jaakola, L.; Aronen, T. Reliable and practical methods for cryopreservation of embryogenic cultures and cold storage of somatic embryos of Norway spruce. Cryobiology 2017, 76, 8-17. [CrossRef] [PubMed]

9. Cyr, D.R.; Lazaroff, W.R.; Grimes, S.M.; Quan, G.; Bethune, T.D.; Dunstan, D.I.; Roberts, D.R. Cryopreservation of interior spruce (Picea glauca engelmannii complex) embryogenic cultures. Plant Cell Rep. 1994, 13, 574-577. [CrossRef] [PubMed]

10. Find, J.; Floto, F.; Krogstrup, P.; Møller, J.D.; Nørgaard, J.V.; Kristensen, M.M.H. Cryopreservation of an embryogenic suspension culture of Picea sitchensis and subsequent plant regeneration. Scand. J. For. Res. 1993, 8, 156-162. [CrossRef]

11. Hazubska-Przybył, T.; Chmielarz, P.; Michalak, M.; Bojarczuk, K. Cryopreservation of embryogenic tissues of Picea omorika (Serbian spruce). Plant Cell Tissue Organ Cult. 2010, 102, 35-44. [CrossRef]

12. Häggman, H.M.; Ryynänen, L.A.; Aronen, T.S.; Krajnakova, J. Cryopreservation of embryogenic cultures of Scots pine. Plant Cell Tissue Organ Cult. 1998, 54, 45-53. [CrossRef]

13. Klimaszewska, K.; Ward, C.; Cheliak, W. Cryopreservation and plant regeneration from embryogenic cultures of larch (larix X eurolepis) and black spruce (Picea mariana). J. Exp. Bot. 1992, 43, 73-79. [CrossRef]

14. Kong, L.; von Aderkas, P. A novel method of cryopreservation without a cryoprotectant for immature somatic embryos of conifer. Plant Cell Tissue Organ Cult. 2011, 106, 115-125. [CrossRef]

15. Nørgaard, J.V.; Duran, V.; Johnsen, Ø.; Krogstrup, P.; Baldursson, S.; von Arnold, S. Variations in cryotolerance of embryogenic Picea abies cell lines and the association to genetic, morphological, and physiological factors. Can. J. For. Res. 1993, 23, 2560-2567. [CrossRef]

16. Adams, G.W.; Kunze, H.A.; McCartney, A.; Millican, S.; Park, Y.-S. An industrial perspective on the use of advanced reforestation stock technologies. In Vegetative Propagation of Forest Trees; Park, Y.-S., Bonga, J.M., Moon, H.-K., Eds.; Korea Forest Research Institute: Seoul, Korea, 2016; pp. 323-334.

17. Lelu-Walter, M.-A.; Thompson, D.; Harvengt, L.; Sanchez, L.; Toribio, M.; Pâques, L.E. Somatic embryogenesis in forestry with a focus on Europe: State-of-the-art, benefits, challenges and future direction. Tree Genet. Genomes 2013, 9, 883-899. [CrossRef]

18. Bonga, J.M. A comparative evaluation of the application of somatic embryogenesis, rooting of cuttings, and organogenesis of conifers. Can. J. For. Res. 2015, 45, 379-383. [CrossRef]

19. Carson, M.; Carson, S.; Te Riini, C. Successful Varietal Forestry with Radiata Pine in New Zealand. N. Z. J. For. 2015, 60, 8-11.

20. Thompson, D. Challenges for the large-scale propagation of forest trees by somatic embryogenesis-A review. In Proceedings of the 3rd International Conference of the IUFRO Unit 2.09.02 on "Woody Plant Production Integrating Genetic and Vegetative Propagation Technologies", Vitoria-Gasteiz, Spain, 8-12 September 2014; pp. 81-91.

21. Högberg, K.-A.; Ekberg, I.; Norell, L.; von Arnold, S. Integration of somatic embryogenesis in a tree breeding programme: A case study with Picea abies. Can. J. For. Res. 1998, 28, 1536-1545. [CrossRef] 
22. Majada, J.P.; Sierra, M.I.; Sanchez-Tames, R. Air exchange rate affects the in vitro developed leaf cuticle of carnation. Sci. Hortic. 2001, 87, 121-130. [CrossRef]

23. Tikkinen, M.; Varis, S.; Peltola, H.; Aronen, T. Improved germination conditions for Norway spruce somatic cotyledonary embryos increased survival and height growth of emblings. Trees. submitted.

24. Lelu, M.-A.; Bastien, C.; Klimaszewska, K.; Ward, C.; Charest, P.J. An improved method for somatic plantlet production in hybrid larch (Larix x leptoeuropaea). Part 1. Somatic embryo maturation. Plant Cell Tissue Organ Cult. 1994, 36, 107-115. [CrossRef]

25. Find, J. Changes in endogenous ABA levels in developing somatic embryos of Norway spruce (Picea abies (L.) Karst.) in relation to maturation medium, desiccation and germination. Plant Sci. 1997, 128, 78-83. [CrossRef]

26. Von Arnold, S.; Hakman, I. Regulation of somatic embryo development in Picea abies by abscisic acid (ABA). J. Plant Physiol. 1988, 132, 164-169. [CrossRef]

27. Gutmann, M.; von Aderkas, P.; Label, P.; Lelu, M.-A. Effects of abscisic acid on somatic embryo maturation of hybrid larch. J. Exp. Bot. 1996, 47, 1905-1917. [CrossRef]

28. Lelu, M.-A.; Bastien, C.; Klimaszewska, K.; Ward, C.; Charest, P.J. An improved method for somatic plantlet production in hybrid larch (Larix $\mathrm{x}$ leptoeuropaea). Part 2. Control of germination and plantlet development. Plant Cell Tissue Organ Cult. 1994, 36, 117-127. [CrossRef]

29. Lelu, M.-A.; Label, P. Changes in the levels of abscisic acid and its glucose ester conjugate during maturation of hybrid larch (Larix x leptoeuropaea) somatic embryos, in relation to germination and plantlet recovery. Physiol. Plant. 1994, 92, 53-60. [CrossRef]

30. Attree, S.M.; Fowke, L.C. Embryogeny of gymnosperms: Advances in synthetic seed technology of conifer plants. Plant Cell Tissue Organ Cult. 1993, 35, 1-35. [CrossRef]

31. Attree, S.M.; Pomeroy, M.K.; Fowke, L.C. Development of white spruce (Picea glauca (Moench.) Voss) somatic embryos during culture with abscisic acid and osmoticum, and their tolerance to drying and frozen storage. J. Exp. Bot. 1995, 285, 433-439. [CrossRef]

32. Kong, L.; Yeung, E.C. Effects of silver nitrate and polyethylene glycol on white spruce (Picea glauca) somatic embryo development: Enhancing cotyledonary embryo formation and endogenous ABA content. Physiol. Plant. 1995, 93, 298-304. [CrossRef]

33. Merkle, S.A.; Montello, P.M.; Reece, H.M.; Kong, L. Somatic embryogenesis and cryostorage of eastern hemlock and Carolina hemlock for conservation and restoration. Trees 1994, 28, 1767-1776. [CrossRef]

34. Attree, S.M.; Pomeroy, M.K.; Fowke, L.C. Manipulation of conditions for the culture of somatic embryos of white spruce for improved triacylglycerol biosynthesis and desiccation tolerance. Planta 1992, 198, 395-404. [CrossRef] [PubMed]

35. Bozhkov, P.V.; von Arnold, S. Polyethylene glycol promotes maturation but inhibits further development of Picea abies somatic embryos. Physiol. Plant. 1998, 104, 211-224. [CrossRef]

36. Svobodová, H.; Albrechtová, J.; Kumstýřová, L.; Lipavská, H.; Vágner, M.; Vondráková, Z. Somatic embryogenesis in Norway spruce: Anatomical study of embryo development and influence of polyethylene glycol on maturation process. Plant Physiol. Biochem. 1999, 37, 209-221. [CrossRef]

37. Klimaszewska, K.; Lachance, D.; Pelletier, G.; Lelu, A.-M.; Seguin, A. Regeneration of transgenic Picea glauca, P. mariana, and P. abies after cocultivation of embryogenic tissue with Agrobacterium tumefaciens. In Vitro Cell. Dev. Biol. Plant 2001, 37, 748-755.

38. Litvay, J.D.; Verma, D.C.; Johnson, M.A. Influence of loblolly pine (Pinus taeda L.) culture medium and its components on growth and somatic embryogenesis of wild carrot (Daucus carota L.). Plant Cell Rep. 1985, 4, 325-328. [CrossRef] [PubMed]

39. Belmonte, M.F.; Yeung, E.C. The effects of reduced and oxidized glutathione on white spruce somatic embryogenesis. In Vitro Cell. Dev. Biol. Plant 2004, 40, 61-66. [CrossRef]

40. Klimaszewska, K.; Park, Y.-S.; Overton, C.; Maceacheron, I.; Bonga, J.M. Optimized somatic embryogenesis in Pinus strobus L. In Vitro Cell. Dev. Biol. Plant 2001, 37, 392-399. [CrossRef]

41. Landis, T.D.; Dumroese, R.K.; Haase, D. The Container Tree Nursery Manual. Vol. 6. Seedling Propagation; Agricultural Handbook 674; U.S. Department of Agriculture, Forest Service: Washington, DC, USA, 2010; pp. 3-164.

42. Rikala, R. Metsäpuiden Paakkutaimien Kasvatusopas (Container Seedling Growing Manual for Forest Trees); The Finnish Forest Research Institute: Suonenjoki, Finland, 2012; 247 p. 
43. Nygren, M. Metsäpuiden Sisemenopas (Seedling Guide for Forest Trees); Metsäntutkimuslaitoksen Tiedonantoja: Suonenjoki, Finland, 2003; Volume 882, 144 p.

44. Högberg, K.-A. Possibilities and limitations of vegetative propagation of Norway spruce. In Acta Universitatis Agriculturae Sueciae, Silvestria 294; Swedish University of Agricultural Sciences: Uppsala, Switzerland, 2003.

45. Von Aderkas, P.; Kong, L.; Prior, N.A. In Vitro techniques for conifer embryogenesis. In Vegetative Propagation of Forest Trees; Park, Y.-S., Bonga, J.M., Moon, H.-K., Eds.; Korea Forest Research Institute: Seoul, Korea, 2016; pp. 335-350.

46. Tikkinen, M.; Varis, S.; Peltola, H.; Aronen, T. Norway spruce Emblings as Cutting Donors for Tree Breeding and Production. Scand. J. For. Res. 2017, 33, 207-214. [CrossRef]

47. Haapanen, M. Clones in Finnish tree breeding. In Proceedings of the Nordic Meeting Held in September 10th-11th 2008 at Punkaharju, Finland; Working papers of the Finnish Forest Research Institute; Finnish Forest Research Institute: Vantaa, Finland, 2009; Volume 114, pp. 16-19.

(C) 2018 by the authors. Licensee MDPI, Basel, Switzerland. This article is an open access article distributed under the terms and conditions of the Creative Commons Attribution (CC BY) license (http://creativecommons.org/licenses/by/4.0/). 